\title{
Isoflurane Protects Human Kidney Proximal Tubule Cells against Necrosis via Sphingosine Kinase and Sphingosine-1-Phosphate Generation
}

\author{
Mihwa Kim ${ }^{a}$ Minjae Kim ${ }^{a}$ Sang Won Park ${ }^{a}$ Stuart M. Pitson ${ }^{b} \quad$ H. Thomas Lee ${ }^{a}$ \\ ${ }^{\text {a } D e p a r t m e n t ~ o f ~ A n e s t h e s i o l o g y, ~ C o l l e g e ~ o f ~ P h y s i c i a n s ~ a n d ~ S u r g e o n s ~ o f ~ C o l u m b i a ~ U n i v e r s i t y, ~ N e w ~ Y o r k, ~ N . Y ., ~ U S A ; ~}$ \\ ${ }^{b}$ Molecular Signalling Laboratory, Centre for Cancer Biology, SA Pathology, Adelaide, S.A., Australia
}

\section{Key Words}

Kidney injury, acute $\cdot$ Renal failure, acute $\cdot$ Proximal tubule $\cdot$ Anesthetics, volatile

\begin{abstract}
Background/Aims: We previously showed that the inhalational anesthetic isoflurane protects against renal ischemia reperfusion injury in part via sphingosine kinase (SK)-mediated synthesis of sphingosine-1-phosphate (S1P). In this study, we tested the hypothesis that isoflurane directly targets renal proximal tubule cells via SK activation, S1P synthesis and activation of S1P receptors to initiate cytoprotective signaling. Methods and Results: Isoflurane-mediated phosphorylation of extracellular signal-regulated kinase (ERK) and Akt and induction of HSP70 in human kidney proximal tubule (HK-2) cells were inhibited by dimethylsphingosine (DMS), an SK inhibitor, and VPC23019, an $\mathrm{S1P}_{1 / 3}$ receptor selective antagonist, in $\mathrm{HK}-2$ cells. A selective $\mathrm{S}_{1} \mathrm{P}_{1}$ receptor agonist, SEW2781, mimicked isoflurane-induced phosphorylation of ERK and Akt and induction of HSP70. Moreover, isoflurane-mediated protection against $\mathrm{H}_{2} \mathrm{O}_{2}$-induced necrosis of $\mathrm{HK}-2$ cells was significantly attenuated by an $\mathrm{S1P}_{1 / 3}$ receptor antagonist, VPC23019, and by SK inhibitors DMS or 4-[[4(4-chlorophenyl)-2-thiazolyl]amino]phenol. Finally, overexpression of the SK1 enzyme in HK-2 cells protected against
\end{abstract}

$\mathrm{H}_{2} \mathrm{O}_{2}$-induced necrosis. Conclusions: Collectively, our study demonstrates that S1P released via isoflurane-mediated SK1 stimulation produces direct anti-necrotic effects probably via $\mathrm{S}_{1} \mathrm{P}_{1}$ receptor-mediated cytoprotective signaling (ERK/ Akt phosphorylation and HSP70 induction) in HK-2 cells. Our findings may help to unravel the cellular signaling pathways of volatile anesthetic-mediated renal protection and lead to new therapeutic applications of volatile anesthetics during the perioperative period.

Copyright $\odot 2010$ S. Karger AG, Basel

\section{Introduction}

Perioperative acute kidney injury (AKI) due to renal ischemia and reperfusion (IR) injury is a frequent and devastating complication that lacks effective therapy [1]. Development of perioperative AKI leads to high mortality and is frequently complicated by many other lifethreatening conditions including respiratory failure, sepsis and a multi-organ dysfunction syndrome [2]. Unfortunately, the mortality and morbidity rate from peri-

This work was funded by National Institute of Health grant RO1GM067081.

\section{KARGER}

(C) 2010 S. Karger AG, Basel

Fax +41613061234

E-Mail karger@karger.ch

www.karger.com
Accessible online at:

www.karger.com/ajn
H. Thomas Lee, $\mathrm{MD}, \mathrm{PhD}$

Department of Anesthesiology, Anesthesiology Research Laboratories

Columbia University, P\&S Box 46 (PH-5), 630 West 168th Street

New York, NY 10032-3784 (USA)

Tel. +1 212305 7416, Fax +1 212305 8980, E-Mail tl128@ columbia.edu 
operative AKI subsequently leading to renal failure has changed little over the past 50 years [1].

Volatile anesthetics are administered to virtually all patients subjected to general anesthesia in the United States. Volatile anesthetics, in addition to their anesthetic effects, have non-anesthetic properties in many organ systems including the kidney [3,4]. We demonstrated previously that volatile anesthetics including isoflurane (2-chloro-2-(difluoromethoxy)-1,1,1-trifluoro-ethane) at a minimum alveolar concentration (MAC) of 1 (defined as the percent concentration in the alveolus of an inhaled anesthetic agent required to prevent $50 \%$ of subjects from moving in response to a painful stimulus when used as the sole anesthetic) protected against renal injury in vivo by reducing necrosis and inflammation $[3,5,6]$. Subsequently, we demonstrated that the volatile anesthetic isoflurane activates sphingosine kinase-1 (SK1) with increased sphingosine-1-phosphate (S1P) synthesis to mediate the renal protective effects in vivo [7].

We have also demonstrated previously that volatile anesthetics (0.5-2 MAC) provided significant cytoprotection and produced anti-necrotic and anti-inflammatory effects on cultured renal proximal tubules via direct activation of cytoprotective kinases (ERK, MAPK and Akt) and the induction of HSP70 [8]. In our previous in vivo studies we did not identify the specific cell type(s), e.g. proximal tubules versus leukocytes, targeted by SK activation in mediating the renal protective effects of volatile anesthetics. Reduction of renal IR injury via S1P receptor activation has been demonstrated by others [9-11] and the major mechanisms involved are proposed to be attenuation of the inflammatory response during and after IR via $\mathrm{S}_{1} \mathrm{P}_{1}$ receptor activation. $\mathrm{S}_{1} \mathrm{P}_{1}$ receptor-mediated modulation of the inflammatory response is well known including effects on lymphocyte egress and subsequent lymphopenia. However, it remains to be determined whether volatile anesthetic-mediated SK1 activation and S1P release reduce renal IR injury via direct protective effects on renal tubule cells. Specifically, it is not known whether volatile anesthetic-mediated S1P release provides direct renal tubule cell protection via $\mathrm{S}_{1} \mathrm{P}_{1}$ receptor activation.

Therefore, in this study we tested the hypothesis that isoflurane directly protects human kidney proximal tubule (HK-2) cells in culture against oxidant $\left(\mathrm{H}_{2} \mathrm{O}_{2}\right)$-induced necrosis via SK1 activation and release of S1P with subsequent activation of S1P receptors (effects completely independent of S1P-mediated lymphopenia observed in vivo). We used cultures of human renal proximal tubules as this is the renal cell type most susceptible to ne- crosis after renal IR injury $[12,13]$. In addition, we determined whether lentivirus-mediated overexpression of the SK-1 enzyme would provide increased resistance against oxidant-induced necrosis in HK-2 cells.

\section{Materials and Methods}

2-Chloro-2-(difluoromethoxy)-1,1,1-trifluoro-ethane (isoflurane) was purchased from Abbott Laboratories (North Chicago, Ill., USA). N,N-Dimethylsphingosine (DMS) was purchased from Biomol International (Plymouth Meeting, Mass., USA). 4-[[4-(4-Chlorophenyl)-2-thiazolyl]amino]phenol (SKI-II) was purchased from Tocris Bioscience (Ellisville, Mo., USA). (R)Phosphoric acid mono-[2-amino-2-(3-octyl-phenylcarbamoyl)ethyl] ester (VPC23019) was purchased from Avanti Polar Lipids (Alabaster, Ala., USA). 5-[4-Phenyl-5-(trifluoromethyl)thiophen2-yl]-3-[3-(trifluoromethyl)phenyl]1,2,4-oxadiazole (SEW-2871) was obtained from Tocris Bioscience. Unless otherwise specified, all other reagents were purchased from Sigma (St. Louis, Mo., USA).

\section{HK-2 Cell Culture and Generation of SK1-Overexpressing}

HK-2 Cells

HK-2 cells (immortalized human proximal tubular cell line, American Type Culture Collection, Manassas, Va., USA) were grown and passaged in culture medium (50:50 mixture of DMEM low glucose and F12 plus 5\% serum) and antibiotics (100 U/ml of penicillin G, $100 \mu \mathrm{g} / \mathrm{ml}$ of streptomycin, and $0.25 \mu \mathrm{g} / \mathrm{ml}$ of amphotericin B) at $37^{\circ} \mathrm{C}$ in a $100 \%$ humidified atmosphere of $5 \%$ $\mathrm{CO}_{2}-95 \%$ air. All of the treatments were performed after cells were maintained for $24 \mathrm{~h}$ in serum-free basal media.

We generated HK-2 cells overexpressing wild-type SK1 [14] by infecting HK-2 cells with SK1 encoding lentivirus. Lentivirus encoding wild-type SK1 were produced by subcloning the SK1 cDNA into a modified shuttle vector CMV-pLL3.7 where the insert expression is driven by a CMV promoter followed by an IRES-enhanced green fluorescent protein (EGFP) sequence for simultaneous co-expression of 2 independent proteins; the EGFP reporter gene and SK1 fused to a hemagglutinin (HA) tag. Lentivirus was produced by a triple transfection of CMV-SK1-pLL3.7 $(10 \mu \mathrm{g})$, pVSVG (Vesicular stomatitis virus G, Invitrogen, Carlsbad, Calif., USA; $7 \mu \mathrm{g}$ ), and p $\Delta 8.9$ (from Dr. Van Parjs, MIT, Cambridge Mass., USA; $5 \mu \mathrm{g}$ ) as described [15]. In brief, CMV-SK1pLL3.7 and the 2 packaging vectors were cotransfected into $80-$ 90\% confluent HEK-293FT cells in $10-\mathrm{cm}$ tissue culture plates using $20 \mu$ l of Lipofectamine 2000 (Invitrogen) in serum-free OptiMEM medium according to the manufacturer's recommendations. Supernatant was collected after $48 \mathrm{~h}$ and passed through a $0.45-\mu \mathrm{m}$ filter to remove cells and debris. An approximate viral titer was determined by infecting HEK293 cells with serial dilutions of the final virus suspension and counting the number of fluorescent cells $48 \mathrm{~h}$ after infection. We typically obtained titers of $2-5 \times 10^{6}$ infectious units $/ \mathrm{ml}$ starting from one $10-\mathrm{cm}$ plate of HEK293FT cells. Cell culture medium was removed from HK-2 cells growing on 6-well plates and replaced with $1.5 \mathrm{ml}$ of lentivirus medium and incubated at $37^{\circ} \mathrm{C}$. After $48 \mathrm{~h}$, the lentivirus medium was replaced with cell culture medium and infected HK-2 cells were propagated and used for studies. 


\section{Exposure of HK-2 Cells to Isoflurane}

For isoflurane treatment, HK-2 cells in $10-\mathrm{cm}$ plates were placed in an airtight, $37^{\circ} \mathrm{C}$, humidified modular incubator chamber (Billups-Rothenberg, Inc., Del Mar, Calif., USA) with inflow and outflow connectors as described previously $[8,16]$. The inlet port was connected to an in-line calibrated agent specific vaporizer (Datex-Ohmeda) to deliver varying concentrations of isoflurane $(2.5 \%)$ mixed with carrier gas $\left(95 \%\right.$ air and $\left.5 \% \mathrm{CO}_{2}\right)$ at 10 liters/min. The outlet port was connected to a Datex-Ohmeda 5250 RGM gas analyzer that measured volatile anesthetic concentrations. We previously demonstrated that clinically relevant concentrations of volatile anesthetics (0.5-2 MAC) produced cytoprotective signaling in HK-2 cells [8]. For this study, we exposed HK-2 cells to $1-2 \mathrm{MAC}$ or $1.2-2.5 \%$ isoflurane for $4-14 \mathrm{~h}$ at $37^{\circ} \mathrm{C}$. Control cells were exposed to carrier gas in an identical modular incubator chamber.

Some HK-2 cells were pretreated with a selective $\mathrm{S}_{1} \mathrm{P}_{1}$ receptor agonist (SEW-2781, $1 \mu \mathrm{M}$ ) for either 5-180 min or for 1-24 h instead of isoflurane treatment. Separate cohorts of HK-2 cells were pretreated for $30 \mathrm{~min}$ with either a selective $\mathrm{S}_{1} \mathrm{P}_{1 / 3}$ receptor antagonist VPC23019 (10-100 $\mu \mathrm{M})$, or sphingosine kinase inhibitors; DMS $(10-100 \mu \mathrm{M})$ or SKI-II $(5 \mu \mathrm{M})$, and exposed to $2.5 \%$ isoflurane. In preliminary experiments, we were able to demonstrate that DMS and SKI-II inhibited SK activity [7] in a concentration-dependent fashion in mouse kidney and HK-2 cell extracts.

\section{Induction of HK-2 Cell Necrosis}

In preliminary studies, we determined that isoflurane treatment failed to attenuate apoptosis, induced with tumor necrosis factor- $\alpha$ (TNF- $\alpha, 10 \mathrm{ng} / \mathrm{ml})$ plus cycloheximide $(5 \mu \mathrm{g} / \mathrm{ml})$ for $16 \mathrm{~h}$, in HK-2 cells (assessed with DNA laddering, PARP and caspase 3 immunoblotting). Confluent HK-2 cells, EGFP HK-2 cells and EGFP-SK1 HK-2 cells were incubated with $2.5 \%$ isoflurane for $14 \mathrm{~h}$ and subjected to necrotic injury with $2 \mathrm{mM} \mathrm{H}_{2} \mathrm{O}_{2}$ for 0 $6 \mathrm{~h}$ as described [17]. We determined in preliminary studies that the ability of $\mathrm{H}_{2} \mathrm{O}_{2}$ to kill HK-2 cells is dose- and time-related. High (e.g. 1-10 mM) doses of $\mathrm{H}_{2} \mathrm{O}_{2}$ killed cells rapidly (within $1 \mathrm{~h}$ ), whereas lower doses (e.g. 1-10 $\mu \mathrm{M}$ ) killed cells more slowly. Our preliminary studies also showed that our treatment with $\mathrm{H}_{2} \mathrm{O}_{2}$ (for 1-6 h) causes negligible apoptosis (PARP and capase 3 immunoblotting and DNA laddering).

\section{Measurement of Cell Viability with $\mathrm{LDH}$}

$\mathrm{LDH}$ released into cell culture media as indices of rapid, necrotic cell death were measured using an LDH assay kit from Promega (Madison, Wisc., USA). Released LDH from cells was expressed as a percentage of total cellular LDH ( $\mathrm{LDH}$ released into the media following cell lysis with $1 \%$ Triton-X for $5 \mathrm{~min}$ ).

\section{Immunoblot Analyses}

Immunoblotting analyses were performed as described previously [18]. The primary antibodies for phospho-ERK1/2, total ERK and $\beta$-actin were from Santa Cruz Biotechnologies (Santa Cruz, Calif., USA). The primary antibody for total HSP70, phospho-Akt and total Akt1 were from Cell Signaling Technologies (Danvers, Mass., USA). The primary antibodies for $\mathrm{S}_{1} \mathrm{P}_{1}$ and $\mathrm{S}_{1} \mathrm{P}_{3}$ receptors were obtained from Cayman Chemical (Ann Arbor, Mich., USA). The primary antibodies for $\mathrm{S}_{2} \mathrm{P}_{2}, \mathrm{~S}_{1} \mathrm{P}_{4}$ and $\mathrm{S}_{\mathrm{P}} \mathrm{P}$ receptors were from GenWay Biotech, Inc. (San Diego, Calif., USA).
The antibody for the inducible form of HSP-70 was from Stressgen Biotechnologies (San Diego, Calif., USA). The primary antibody for SK1 was from ECM Biosciences (Versailles, Ky., USA). Phospho-ERK or phospho-Akt blots were stripped and reprobed for total ERK or total Akt1. The secondary antibody (goat anti-rabbit or anti-mouse IgG conjugated to horseradish peroxidase at 1:5,000 dilution) was detected with enhanced chemiluminescence immunoblotting detection reagents (Amersham), with subsequent exposure to a CCD camera coupled to a UVP Bio-imaging System (Upland, Calif., USA) and a personal computer. The band intensities of the immunoblots were within the linear range of exposure for all experiments.

High-Pressure Liquid Chromatography Detection of S1P

Confluent HK-2 cells were sonicated in PBS (pH 7.2). Aliquots were used for protein assay and the remainder of HK-2 cellular lysates were processed for high-pressure liquid chromatography (HPLC) to measure S1P levels as described by Min et al. [19] with two steps of sample pretreatment: enzymatic dephosphorylation of S1P by alkaline phosphatase (100 U/sample, Sigma) and subsequent analysis of o-phthalaldehyde derivatives of the liberated sphingosine bases by HPLC. By introducing C17 S1P (Avanti Polar Lipids, Inc.) as an internal standard, S1P present in a sample can be quantified on a $\mathrm{C} 18$ reversed-phase column with a simple mobile phase of acetonitrile:deionized distilled water $(89: 11, \mathrm{v} / \mathrm{v})$ and expressed as fold increase over the carrier gas-treated group.

\section{Reverse Transcription-Polymerase Chain Reactions for SK1}

and $S 1 P_{1-5}$ Receptors

We detected mRNA expression of S1P receptor subtypes 1-5 with reverse transcription-polymerase chain reaction (RT-PCR) as described previously using the Access RT-PCR System (Promega) [17]. We also tested for the overexpression of SK1 mRNA after lentivirus infection in $\mathrm{HK}-2$ cells. $\mathrm{SK} 1$ and $\mathrm{S}_{1} \mathrm{P}_{1-5}$ primers were designed based on published GenBank sequences for human (table 1) and to amplify a genomic region that spans one or more introns to eliminate the confounding effect of amplifying contaminating genomic DNA. For each experiment, we also performed semiquantitative RT-PCR under conditions yielding linear results for GAPDH (table 1) to confirm equal RNA input.

SK1 Activity Assay

SK1 activity was measured as described by Vessey et al. [20] with some modification as described [7].

\section{Statistical Analysis}

The data were analyzed with Student's t test when comparing means between 2 groups or with one-way analysis of variance plus Bonferroni post hoc multiple comparison test to compare mean values across multiple treatment groups. In all cases, a probability statistic $<0.05$ was taken to indicate significance. All data are expressed throughout the text as mean \pm SEM.

\section{Protein Determination}

Protein content was determined with the Pierce Chemical (Rockford, Ill., USA) bicinchoninic acid protein assay reagent with BSA as a standard. 
Fig. 1. Total RNA from HK-2 cells was extracted and subjected to RT-PCR. Molecular weight (M) markers are shown on the left. Messenger RNAs encoding 5 subtypes of S1P receptors (R) are present in human proximal tubule (HK-2) cells. Representative of 4 experiments.

Fig. 2. Isoflurane (2.5\% for 3,6 or $14 \mathrm{~h})$ increases S1P synthesis in HK-2 cells $(n=5)$ compared to carrier gas-treated cells $(\mathrm{n}=$ 6). PMA (100 $\mu$ M for $6 \mathrm{~h}, \mathrm{n}=5)$ was used as a positive control. ${ }^{*} \mathrm{p}<0.05$ vs. carrier gas-treated cells.
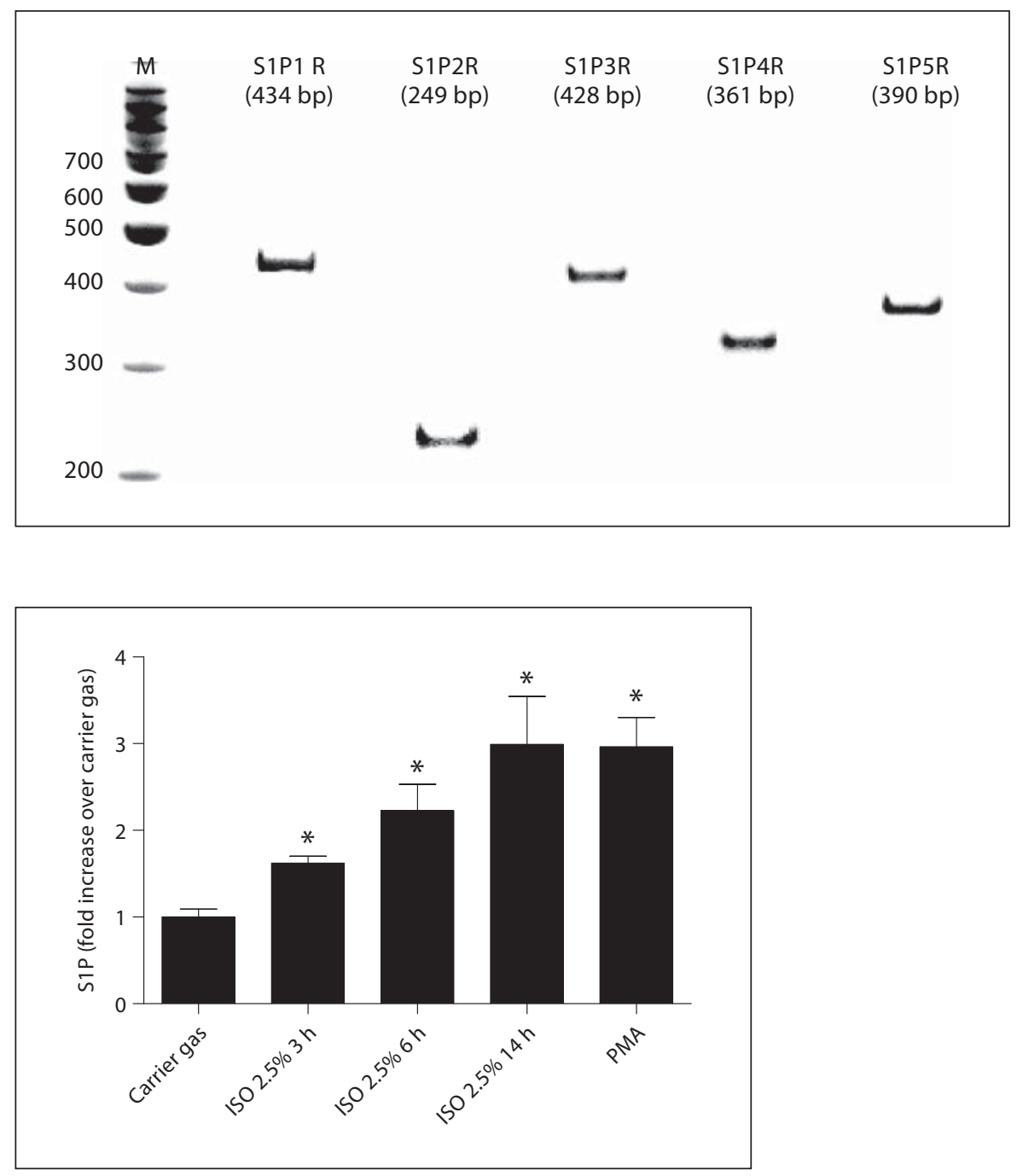

Table 1. Primer sequences

\begin{tabular}{|c|c|c|c|c|}
\hline Primers & Species & Size, bp & Sequence, sense/antisense & Annealing, ${ }^{\circ} \mathrm{C} /$ cycle No. \\
\hline GAPDH & Human & 450 & $\begin{array}{l}\text { 5'-ACCACAGTCCATGCCATCAC-3' } \\
5^{\prime} \text {-CACCACCCTGTTGCTGTAGCC-3' }\end{array}$ & $65 / 15$ \\
\hline SK-1 & Human & 330 & $\begin{array}{l}\text { 5'-ATCTCCTTCACGCTGATGC-3' } \\
\text { 5'-GTGCAGAGACAGCAGGTTCA-3' }\end{array}$ & $66 / 26$ \\
\hline$\overline{\mathrm{S} 1 \mathrm{P} 1}$ & Human & 434 & $\begin{array}{l}\text { 5'-CGAGAGCACTACGCAGTCAG-3' } \\
5^{\prime} \text {-AGCAGCAGATGAGAATGAAC-3' }\end{array}$ & $64 / 19$ \\
\hline S1P2 & Human & 249 & $\begin{array}{l}\text { 5'-GCCTAGCCAGTTCTGAAAGC-3' } \\
\text { 5'-GAGTGGAACTTGCTGTT-3' }\end{array}$ & $58 / 22$ \\
\hline S1P3 & Human & 428 & $\begin{array}{l}\text { 5' -ATCTGGCATTCGAGCGCAGG-3' } \\
5^{\prime} \text {-GGCAATCAAAACCATCAGGT-3' }\end{array}$ & $64 / 27$ \\
\hline $\mathrm{S} 1 \mathrm{P} 4$ & Human & 361 & $\begin{array}{l}\text { 5' -ACATCACGCTGAGTGACCTG-3' } \\
\text { 5' }^{\prime} \text {-AAGAGGATGTAGCGCTTGGA-3' }\end{array}$ & $66 / 27$ \\
\hline S1P5 & Human & 390 & $\begin{array}{l}5^{\prime} \text {-ACCAGGGCGCAGACCTTG-3' } \\
5^{\prime} \text {-AGTGAGTGCCACGAAGACG-3' }\end{array}$ & $62 / 27$ \\
\hline
\end{tabular}




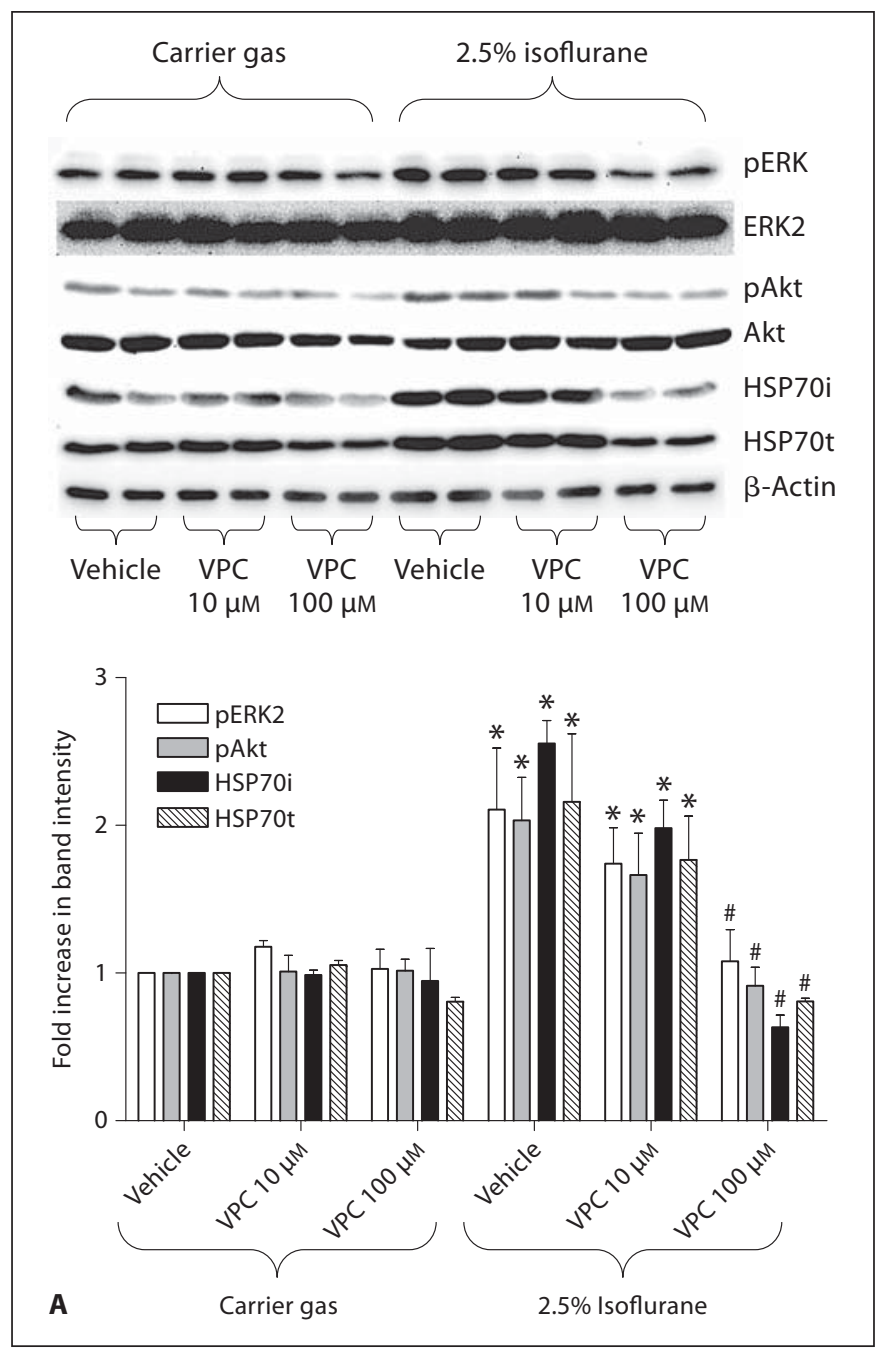

Fig. 3. A A selective $\mathrm{S}_{1} \mathrm{P}_{1 / 3}$ receptor antagonist VPC23019 (VPC, 10 or $100 \mu \mathrm{M}$ ) attenuates isoflurane (2.5\%)-induced ERK and Akt phosphorylation ( $4 \mathrm{~h}$ treatment) and HSP70 induction (14 h treatment). Representative of 4 independent experiments. B Inhibition of sphingosine kinase (SK) with dimethylsphingosine (DMS, 10 or $100 \mu \mathrm{M}$ ) also attenuated the isoflurane-mediated phosphoryla-

\section{Results}

\section{Expression of $\mathrm{S}_{1} P_{1-5}$ Receptors in HK-2 Cells}

With RT-PCR, we show that mRNAs for all 5 S1P receptor subtypes $\left(\mathrm{S}_{1} \mathrm{P}_{1-5}\right)$ are present in $\mathrm{HK}-2$ cells (fig. 1, representative of 4 experiments). No bands were detected after RT-PCRs in water blanks with $\mathrm{S}_{1} \mathrm{P}_{1-5}$ primers or with GAPDH primers. Moreover, with immunoblotting we also determined that proteins for all $5 \mathrm{~S} 1 \mathrm{P}$ receptor subtypes are present in HK-2 cells (data not shown).

Isoflurane Protects HK-2 Cells via SK and S1P

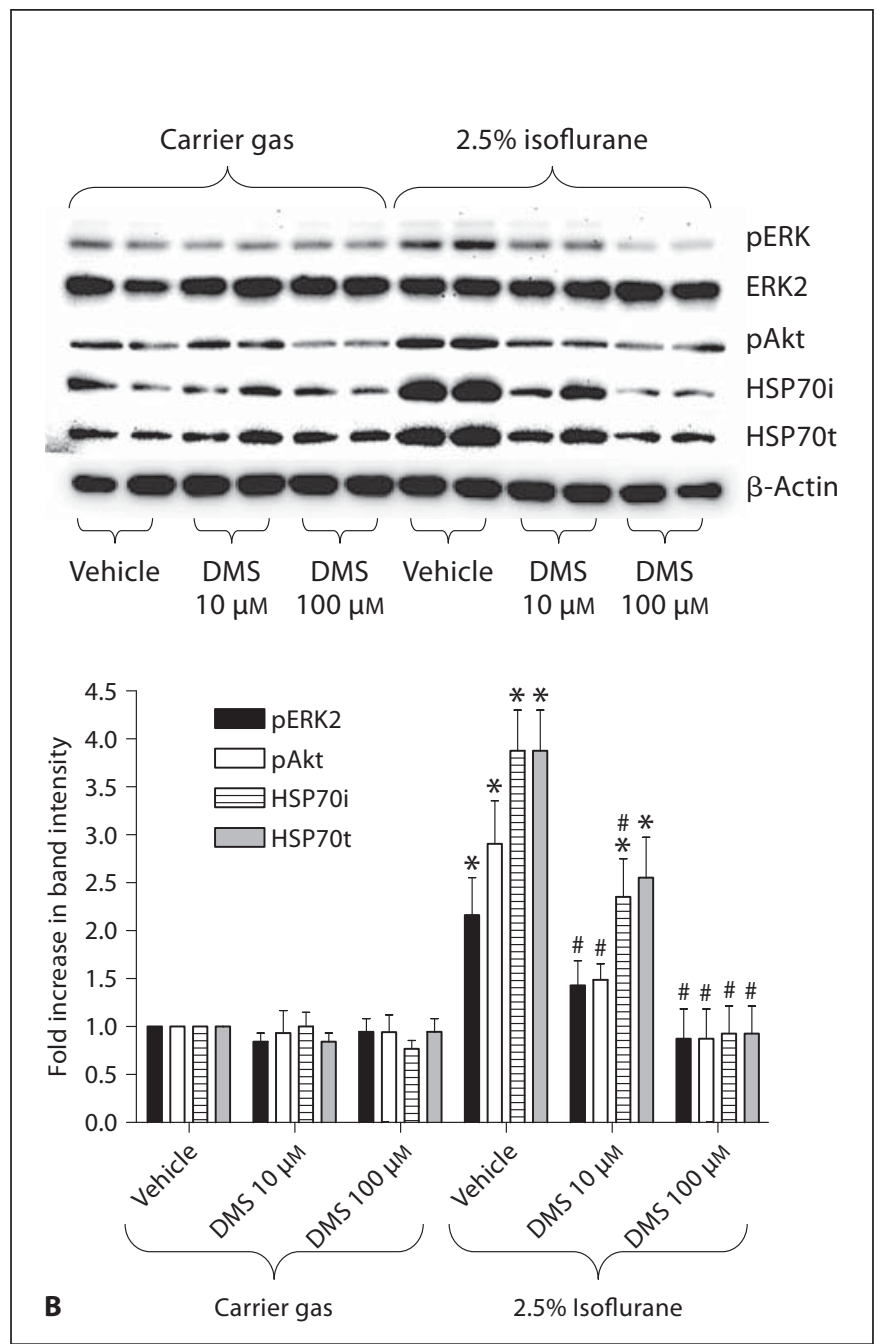

tion of ERK and Akt and induction of HSP70 in HK-2 cells. Representative of 4 independent experiments. Bottom panel of each figure shows densitometric quantifications of relative band intensities for immunoblotting experiments $(n=4) .{ }^{*} p<0.05$ vs. vehicle-treated cells in carrier gas group. ${ }^{\#} \mathrm{p}<0.05$ vs. vehicle-treated cells in isoflurane group. Means $\pm \mathrm{SE}$.

\section{Isoflurane Increases S1P Synthesis in HK-2 Cells}

We utilized HPLC to measure the formation of S1P in $\mathrm{HK}-2$ cells after carrier gas ( $95 \%$ room air plus $5 \% \mathrm{CO}_{2}$ for $14 \mathrm{~h}$ ) or isoflurane treatment. We demonstrate that a clinically relevant concentration of isoflurane increases S1P synthesis in HK-2 cells in a time-dependent manner (fig. 2). Isoflurane (2.5\% or $2 \mathrm{MAC}$ ) treatment for 3,6 or $14 \mathrm{~h}$ increased S1P formed in HK-2 cell lysates to $1.6 \pm$ 0.08 -fold ( $\mathrm{n}=5, \mathrm{p}<0.05), 2.2 \pm 0.3$-fold $(\mathrm{n}=5, \mathrm{p}<0.05)$ and $3.0 \pm 0.55$-fold $(\mathrm{n}=5, \mathrm{p}<0.05)$, respectively, compared to the carrier gas-treated group (fig. 2). The protein 

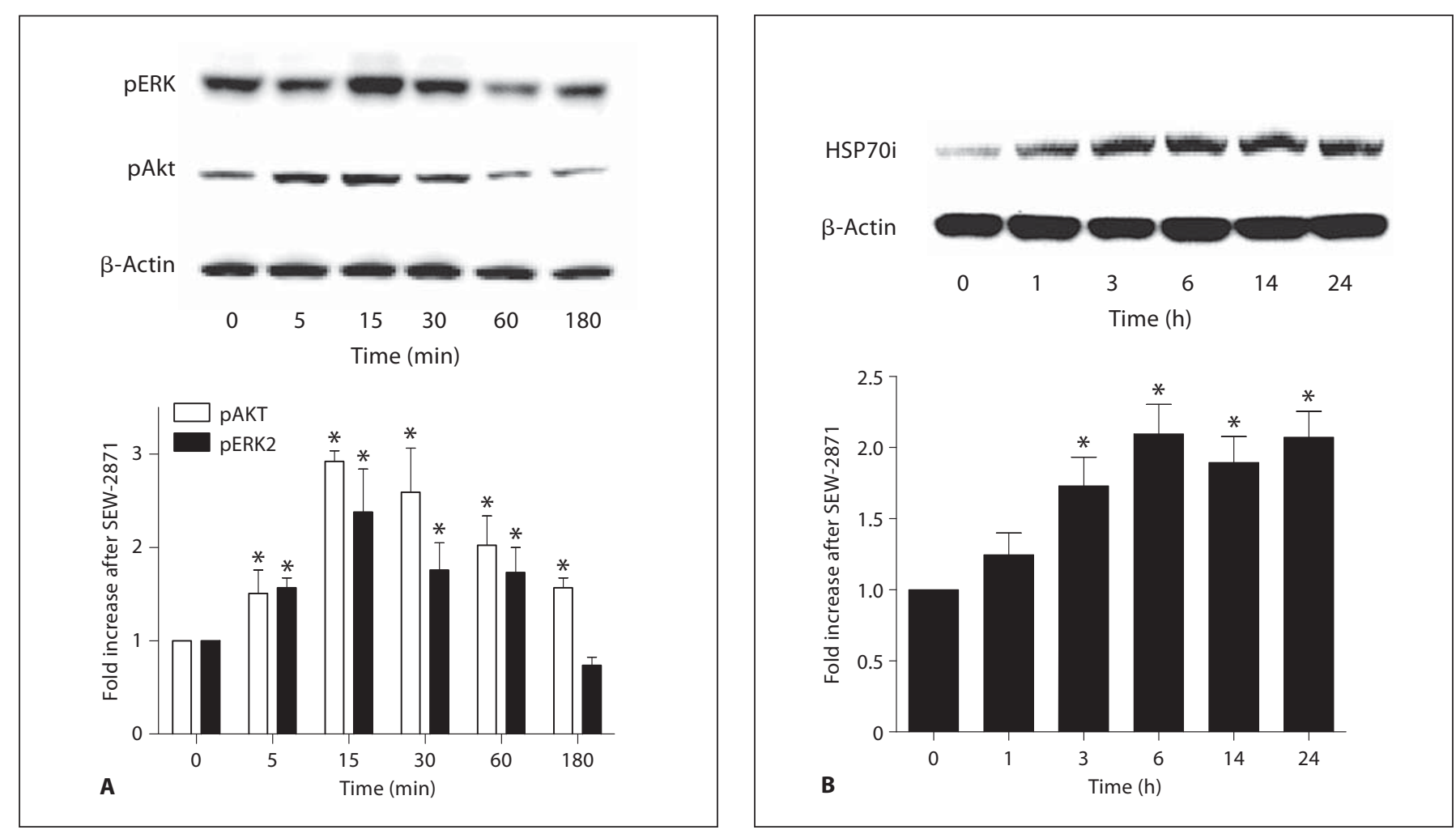

Fig. 4. A selective $\mathrm{S}_{1} \mathrm{P}_{1}$ receptor agonist (SEW-2871, $\left.1 \mu \mathrm{M}\right)$ phosphorylates ERK MAPK and Akt (5-180 min treatment, A) and upregulates HSP70 (1-24 h treatment, B) in HK-2 cells. Representative of 4 separate experiments. Bottom of each panel shows densitometric quantifications of relative band intensities for immunoblotting experiments $(n=4) .{ }^{*} \mathrm{p}<0.05$ vs. time zero. Means \pm SE.

kinase Cactivator, phorbol 12-myristate 13-acetate(PMA), was used as a positive control for SK stimulation and S1P synthesis. PMA (100 $\mu \mathrm{M}$ for $6 \mathrm{~h}$ ) increased S1P synthesis compared to the carrier gas-treated group (fig. 2).

\section{$S 1 P_{1 / 3}$ Receptor Antagonism or SK Inhibition}

Attenuates Isoflurane-Mediated Phosphorylation of

ERK MAPK and Akt and Induction of HSP70

We have previously demonstrated that volatile anesthetics induce ERK/Akt phosphorylation and HSP induction that peak at 4 and $14 \mathrm{~h}$, respectively [18]. HK-2 cells were first treated with a selective $\mathrm{S}_{1} \mathrm{P}_{1 / 3}$ receptor antagonist VPC23019 (10 or $100 \mu \mathrm{M})$ or with vehicle (1\% DMSO) and exposed to $2.5 \%$ isoflurane or to carrier gas $(95 \%$ room air plus $5 \% \mathrm{CO}_{2}$ ) for $4 \mathrm{~h}$ (to induce ERK and $\mathrm{Akt}$ phosphorylation, $\mathrm{n}=4$ ) or $14 \mathrm{~h}$ (to induce HSP70 protein synthesis, $\mathrm{n}=4$ ). VPC23019 attenuated the increases in ERK MAPK and Akt phosphorylation and HSP70 induction in HK-2 cells (fig. 3A). Furthermore, inhibition of SK with DMS (10 or $100 \mu \mathrm{M}, \mathrm{n}=4)$ also attenuated the iso- flurane-mediated phosphorylation of ERK and Akt as well as HSP70 in HK-2 cells (fig. 3B).

\section{Selective S1P 1 Receptor Agonist Mimics Volatile \\ Anesthetic Signaling in HK-2 Cells}

We have previously demonstrated that volatile anesthetics induce phosphorylation of ERK MAPK and Akt as well as upregulation of HSP70 synthesis [8]. Figure 4 shows that a selective $\mathrm{S}_{1} \mathrm{P}_{1}$ receptor agonist (SEW-2871, $1 \mu \mathrm{M})$ acutely but transiently phosphorylates ERK MAPK and Akt proteins (5-180 min treatment; fig. 4A) and upregulates HSP70 protein (1-24 h treatment; fig. 4B) in HK-2 cells $(n=4)$ mimicking the effects of volatile anesthetics in cultured proximal tubule cells.

\section{$S 1 P_{1 / 3}$ Receptor Antagonism or SK Inhibition}

Attenuates Isoflurane-Mediated Protection against

Necrosis in HK-2 Cells

We have demonstrated previously that $\mathrm{HK}-2$ cells are subject to rapid necrosis when treated with $\mathrm{H}_{2} \mathrm{O}_{2}$ in a 
dose- (1-5 mM) and time- (1-6h) dependent manner [21]. Confluent HK-2 cells were incubated with $2.5 \%$ isoflurane or with carrier gas for $14 \mathrm{~h}$ and subjected to necrotic injury with $2 \mathrm{mM} \mathrm{H}_{2} \mathrm{O}_{2}$ for $4 \mathrm{~h}$. Carrier gas-treated HK-2 cells subjected to $\mathrm{H}_{2} \mathrm{O}_{2}$-induced necrosis released significantly increased amounts of intracellular $\mathrm{LDH}$ into the cell culture media compared to the vehicle-treated HK-2 cells. Isoflurane-treated cells released significantly less LDH compared to cells exposed to carrier gas after $\mathrm{H}_{2} \mathrm{O}_{2}$ injury (fig. 5). However, the SK inhibitors (20 $\mu \mathrm{M}$ DMS, $\mathrm{n}=6$, or $5 \mu \mathrm{M}$ SKI-II) or a $\mathrm{S}_{1 / 3}$ receptor antagonist (VPC23019, $20 \mu \mathrm{M}$ ) prevented this protection by isoflurane without affecting cellular necrosis in carrier gas-treated cells (fig. 5).

Overexpression of SK1 Enzyme Increases HK-2 Cell

Resistance against $\mathrm{H}_{2} \mathrm{O}_{2}$-Induced Necrosis

Utilizing lentivirus infection, we overexpressed EGFPSK1 or EGFP in HK-2 cells and generated HK-2 cells stably expressing either EGFP or EGFP-SK1. Figure 6 shows increased protein and mRNA expression in EGFP-SK1 lentivirus-infected HK-2 cells compared to EGFP lentivirus-infected HK-2 cells (representative of 3 experiments). SK enzyme activity in EGFP-SK1-overexpressing HK-2 cells were significantly increased compared to the SK activity in EGFP-overexpressing HK-2 cells ( $3.2 \pm 0.3$-fold, $\mathrm{p}<0.05, \mathrm{n}=4$ ). We subjected control (uninfected) HK-2 cells, EGFP HK-2 cells and EGFP-SK1 HK-2 cells to $\mathrm{H}_{2} \mathrm{O}_{2}$-mediated necrosis ( $2 \mathrm{mM}$ for $0-4 \mathrm{~h}$ ). Figure 7 shows that EGFP-SK1-overexpressing HK-2 cells release significantly less $\mathrm{LDH}$ after $\mathrm{H}_{2} \mathrm{O}_{2}$ injury compared to control HK-2 cells or to EGFP HK-2 cells demonstrating significant resistance to necrosis.

\section{Discussion}

The major findings of this study are that in HK-2 cells: (1) a clinically relevant concentration of isoflurane (2 MAC)-mediated phosphorylation of ERK and Akt and induction of HSP70 was inhibited by the SK inhibitor (dimethylsphingosine) and the $\mathrm{S}_{1 / 3}$ receptor selective antagonist (VPC23019); (2) the selective $\mathrm{S}_{1} \mathrm{P}_{1}$ receptor agonist SEW2781 mimicked isoflurane-induced phosphorylation of ERK and Akt and induction of HSP70; (3) isoflurane-mediated protection against $\mathrm{H}_{2} \mathrm{O}_{2}$-induced necrosis was significantly attenuated by the $\mathrm{S}_{1} \mathrm{P}_{1 / 3}$ receptor antagonist VPC23019 and by the SK inhibitors DMS or SKI-II, and (4) overexpression of the SK1 enzyme in HK-2 cells protected against $\mathrm{H}_{2} \mathrm{O}_{2}$-induced necrosis.

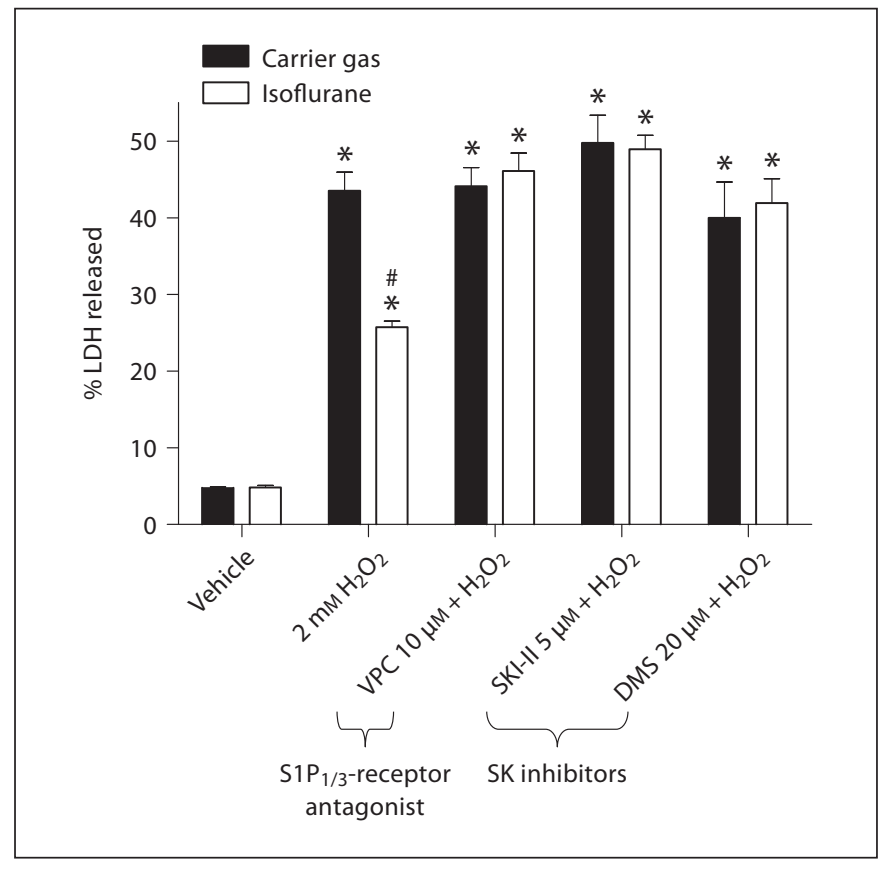

Fig. 5. Inhibition of sphingosine kinase (SK) with dimethylsphingosine (DMS, $20 \mu \mathrm{M}$ ) or with 4-[[4-(4-chlorophenyl)-2-thiazolyl]amino]phenol (SKI-II, $5 \mu \mathrm{M}$ ) or blocking the $\mathrm{S} \mathrm{P}_{1 / 3}$ receptor with VPC-23019 $(10 \mu \mathrm{M})$ prevents isoflurane-mediated protection against $\mathrm{H}_{2} \mathrm{O}_{2}$ necrosis in $\mathrm{HK}-2$ cells. $\mathrm{HK}-2$ cells were incubated with $2.5 \%$ isoflurane or with carrier gas for $14 \mathrm{~h}$ and subjected vehicle treatment or to necrotic injury with $2 \mathrm{mM} \mathrm{H}_{2} \mathrm{O}_{2}$ for $4 \mathrm{~h}$ ( $\mathrm{n}=6$ each). ${ }^{*} \mathrm{p}<0.05$ vs. vehicle-treated cells. ${ }^{*} \mathrm{p}<0.05$ vs. carrier gas-treated cells. Means $\pm \mathrm{SE}$.

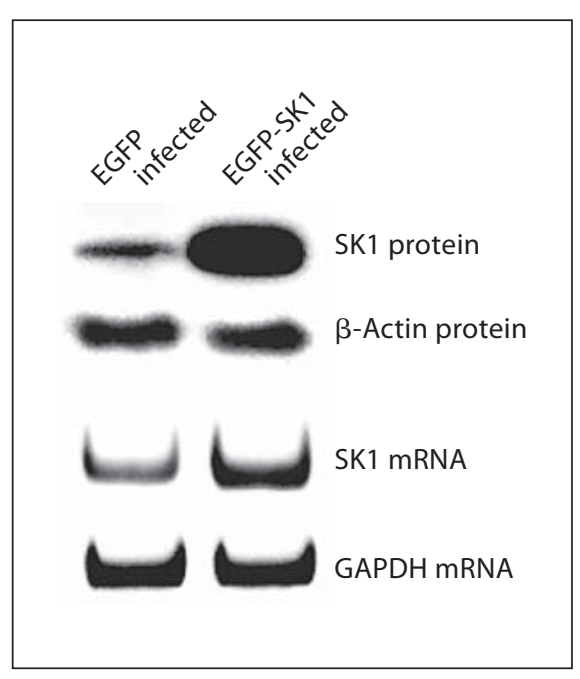

Fig. 6. HK-2 cells infected with EGFP-SK1 encoding lentivirus (EGFP-SK1 cells) for 2 days show increased SK1 protein and mRNA expression compared to EGFP encoding lentivirus-infected cells. Representative of 3 experiments. 


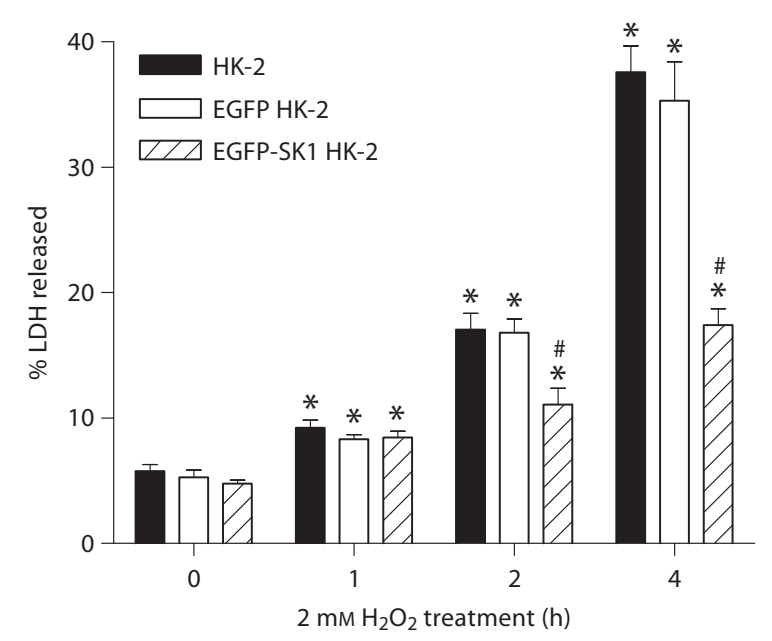

Fig. 7. EGFP-SK1-overexpressing $\mathrm{HK}-2$ cells are protected against $\mathrm{H}_{2} \mathrm{O}_{2}$-induced necrosis. Control HK-2 cells (HK-2, $\mathrm{n}=$ 5), EGFP-overexpressing HK-2 cells (EGFP HK-2, n = 5) or EGFPSK1-overexpressing HK-2 cells (EGFP-SK1 HK-2, $\mathrm{n}=5$ ) were subjected to $0-4$ h of $2 \mathrm{mM} \mathrm{H}_{2} \mathrm{O}_{2}$ treatment. ${ }^{*} \mathrm{p}<0.05$ vs. HK-2 cells at time $0 .{ }^{\#} \mathrm{p}<0.05$ vs. HK-2 cells at each time point.

We demonstrated in previous studies that clinically utilized volatile anesthetics, including isoflurane, provided significant protection against renal IR injury in mice and rats with improved renal function and a profound reduction in renal tubular necrosis $[3,6,7,22]$. Furthermore, we showed that mice anesthetized with isoflurane demonstrated reduced inflammatory changes in the kidney including a reduction in proinflammatory leukocyte influx (neutrophils, lymphocytes and macrophages) as well as decreased proinflammatory mRNA upregulation after renal IR injury in vivo [6]. Our subsequent studies demonstrated that isoflurane stimulates SK enzyme in the murine kidney and this SK activation and release of S1P provided powerful renal protection in a mouse renal IR injury model [7]. The lysophospholipid S1P has been implicated as a cytoprotective signaling molecule balancing against the pro-apoptotic effects of sphingosine and ceramide via the putative 'sphingolipid rheostat' $[23,24]$. In addition, S1P is involved in the regulation of cellular proliferation, cellular migration and angiogenesis as well as the modulation of lymphocyte migration [25]. S1P binds to specific G protein-coupled receptors, of which five are known $\left(\mathrm{S}_{1-5}\right)$ [26].

However, with in vivo studies, it is difficult to determine whether isoflurane-mediated SK activation and S1P release cause direct renal tubular protection and/or cause renal protection via modulating the inflammatory response. Indeed, $\mathrm{S}_{1} \mathrm{P}_{1}$ receptor-mediated immune modulation via inducing lymphopenia is well known [27] and several studies demonstrate powerful protective effects of $S 1 \mathrm{P}_{1}$ receptor activation in a murine model of renal IR injury [9-11]. S1P receptor activation also produces nonlymphocyte-related effects such as mediating TNF- $\alpha$ activation of endothelial cell adhesion molecules via ERK and NF- $\kappa B$ [28], reducing endothelial permeability in acute lung injury [29], and protecting endothelial cells from inflammatory and apoptotic stimuli [30]. In vitro, $\mathrm{S}_{1} \mathrm{P}_{1}$ receptor activation in endothelial cells produces attenuation of endothelial apoptosis with subsequent strengthening of endothelial integrity $[28,31]$. However, the direct protective effect of $\mathrm{S}_{1} \mathrm{P}_{1}$ receptor activation on renal proximal tubular cells independent of lymphocyte modulation has never been examined. Therefore, until this study, it was unknown whether S1P released with volatile anesthetic treatment can directly target proximal tubule cells, the cell type most susceptible to renal IR injury (S3 segments of proximal tubules).

Our previous studies demonstrated direct protective effects of volatile anesthetics on renal proximal tubules suggesting that volatile anesthetics may directly target renal proximal tubule cells to mediate renal protection. We showed previously remarkable protection of the S3 segment of proximal tubules after renal IR injury in rat and mouse models in vivo $[6,22]$. Subsequently, we have demonstrated that volatile anesthetics can directly protect proximal tubule cells against necrosis and inflammation in vitro [8]. Volatile anesthetics also produce cytoprotective signaling cascades (ERK MAPK and Akt phosphorylation and HSP70 induction) in cultured proximal tubule cells [8]. Taken together with the findings of our current study, we propose that isoflurane generates cytoprotective signaling (ERK and Akt phosphorylation and HSP70 induction) and protects against necrosis via SK activation and subsequent activation of S1P receptors in HK-2 cells.

We focused on cultures of proximal tubules (S3 segment origin in particular) as these cells are the primary site of injury in renal IR $[12,32]$. This region of the proximal tubule is marginally oxygenated under normal physiological conditions with a high basal metabolic demand $[12,33]$. Therefore, with IR injury, proximal tubules in the outer medullary zone suffer the most damage. In this study, we injured $\mathrm{HK}-2$ cells with $\mathrm{H}_{2} \mathrm{O}_{2}$ to produce necrosis. We previously demonstrated that $\mathrm{H}_{2} \mathrm{O}_{2}$ causes dose-dependent necrosis in HK-2 cells [34]. Oxygen free radical generation with resultant oxidant tissue 
stress is a major cause of renal reperfusion injury $[35,36]$. During reperfusion after ischemia, reactive oxygen species, such as superoxide anion, hydroxyl radical, and $\mathrm{H}_{2} \mathrm{O}_{2}$, are generated. These reactive oxygen species cause lipid peroxidation of the renal cell membrane with resultant intracellular calcium overload and subsequent necrotic cell death [36-38]. Lack of protection against TNF$\alpha$-and cycloheximide-induced apoptosis with isoflurane treatment suggests that isoflurane-induced S1P release is insufficient to reduce caspase-mediated apoptosis pathways. This is in contrast with the anti-apoptotic effects of S1P in other cell types including endothelial cells $[39,40]$.

We demonstrate an important role for SK/S1P signaling in mediating isoflurane-mediated antinecrotic effects in HK-2 cells (fig. 3-5). We found that two well-known SK inhibitors, DMS and SKI-II, reversed the isoflurane-mediated protection from necrosis with $\mathrm{H}_{2} \mathrm{O}_{2}$ treatment. DMS is a well-known inhibitor of the SK enzyme [5, 21], whereas SKI-II is a newly developed SK inhibitor with a higher potency and selectivity [17]. We were able to demonstrate that SKI-II inhibited SK activity in a concentration-dependent fashion in mouse kidney and HK-2 cell extracts [unpublished data]. We also examined the role of $\mathrm{S} 1 \mathrm{P}$ receptor blockade using the $\mathrm{S}_{1 / 3}$ receptor antagonist VPC23019. VPC23019 behaves as a competitive antagonist at both the $\mathrm{S}_{1} \mathrm{P}_{1}$ and $\mathrm{S}_{1} \mathrm{P}_{3}$ receptors, although it is $\sim 50$-fold more selective for the $\mathrm{S}_{1} \mathrm{P}_{1}$ versus $\mathrm{S}_{1} \mathrm{P}_{3}$ receptor but is completely inactive at the $\mathrm{S}_{1} \mathrm{P}_{2}$ receptor [41]. Pretreatment with VPC23019 was also associated with a reversal of isoflurane-mediated protection against HK-2 cell necrosis. Tak- en together, these data indicate that both increased S1P formation, via an increase in SK enzyme activity, as well as $\mathrm{S}_{1 / 3}$-receptor activation are involved in mediating the protective effects of isoflurane in HK-2 cell necrosis.

One of the limitations of this study is that the data presented in this study are largely pharmacological, which has the potential to have nonspecific effects. Furthermore, although the overexpression data are quite convincing and establish the link between isoflurane and the $\mathrm{S}_{\mathrm{P}} \mathrm{P}_{1}$ receptor, they do not directly address the effect of isoflurane. Isoflurane could still be utilizing additional mechanisms to produce the cytoprotective effects. Studies directly targeting $\mathrm{S}_{1} \mathrm{P}_{1}$ receptor deletion (with $\mathrm{S}_{1} \mathrm{P}_{1}$ receptor knockout mice) or knockdown (with siRNA for $\mathrm{S}_{1} \mathrm{P}_{1}$ receptor) to show elimination of the isoflurane effect should be performed in the future to complement our current studies.

In conclusion, we demonstrated in this study that isoflurane directly activates the SK and S1P receptor signaling pathway in HK-2 cells. Activation of $\mathrm{S}_{1} \mathrm{P}_{1}$ receptors mimicked the signaling pathways of isoflurane in HK-2 cells. We also demonstrated that overexpression of the SK1 enzyme itself can produce protection against $\mathrm{H}_{2} \mathrm{O}_{2}$ induced necrosis in HK-2 cells. These effects of isoflurane can mechanistically explain the powerful reduction in necrosis and inflammation and the severity of renal failure after renal IR injury. Further elucidation of the mechanisms of protection as well conclusive elucidation of the specific S1P receptor subtype may lead to advancements in the treatment of renal IR injury and acute renal failure.

\section{References}

$\checkmark 1$ Jones DR, Lee HT: Perioperative renal protection. Best Pract Res Clin Anaesthesiol 2008;22:193-208.

2 Bonventre JV, Weinberg JM: Recent advances in the pathophysiology of ischemic acute renal failure. J Am Soc Nephrol 2003;14: 2199-2210.

-3 Lee HT, Ota-Setlik A, Fu Y, Nasr SH, Emala CW: Differential protective effects of volatile anesthetics against renal ischemia-reperfusion injury in vivo. Anesthesiology 2004;101: 1313-1324.

4 Chiari PC, Bienengraeber MW, Pagel PS, Krolikowski JG, Kersten JR, Warltier DC: Isoflurane protects against myocardial infarction during early reperfusion by activation of phosphatidylinositol-3-kinase signal transduction: evidence for anesthetic-induced postconditioning in rabbits. Anesthesiology 2005;102:102-109.

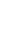

Lee HT, Emala CW, Joo JD, Kim M: Isoflurane improves survival and protects against renal and hepatic injury in murine septic peritonitis. Shock 2007;27:373-379.

6 Lee HT, Kim M, Kim M, Kim N, Billings Iv FT, D’Agati VD, Emala CW Sr: Isoflurane protects against renal ischemia and reperfusion injury and modulates leukocyte infiltration in mice. Am J Physiol Renal Physio 2007;293:F713-F722.

-7 Kim M, Kim M, Kim N, D’Agati VD, Emala CW Sr, Lee HT: Isoflurane mediates protection from renal ischemia-reperfusion injury via sphingosine kinase and sphingosine-1phosphate-dependent pathways. Am J Physiol Renal Physiol 2007;293:F1827-F1835.

$\checkmark 8$ Lee HT, Kim M, Jan M, Emala CW: Anti-inflammatory and anti-necrotic effects of the volatile anesthetic sevoflurane in kidney proximal tubule cells. Am J Physiol Renal Physiol 2006;291:F67-F78. $\checkmark 9$ Awad AS, Ye H, Huang L, Li L, Foss FW Jr, Macdonald TL, Lynch KR, Okusa MD: Selective sphingosine 1-phosphate 1 receptor activation reduces ischemia-reperfusion injury in mouse kidney. Am J Physiol Renal Physiol 2006;290:F1516-F1524.

$\checkmark 10$ Lai LW, Yong KC, Igarashi S, Lien YH: A sphingosine-1-phosphate type 1 receptor agonist inhibits the early T-cell transient following renal ischemia-reperfusion injury. Kidney Int 2007;71:1223-1231.

11 Lien YH, Yong KC, Cho C, Igarashi S, Lai LW: S1P(1)-selective agonist, SEW2871, ameliorates ischemic acute renal failure. Kidney Int 2006;69:1601-1608.

12 Lieberthal W, Nigam SK: Acute renal failure. I. Relative importance of proximal vs. distal tubular injury. Am J Physiol 1998;275:F623F631. 
-13 Ryan MJ, Johnson G, Kirk J, Fuerstenberg SM, Zager RA, Torok-Storb B: HK-2: an immortalized proximal tubule epithelial cell line from normal adult human kidney. Kidney Int 1994;45:48-57.

14 Pitson SM, D’Andrea RJ, Vandeleur L, Moretti PA, Xia P, Gamble JR, Vadas MA, Wattenberg BW: Human sphingosine kinase: purification, molecular cloning and characterization of the native and recombinant enzymes. Biochem J 2000;350:429-441.

-15 Mikami M, Goubaeva F, Song JH, Lee HT, Yang J: Beta-adrenoceptor blockers protect against staurosporine-induced apoptosis in SH-SY5Y neuroblastoma cells. Eur J Pharmacol 2008;589:14-21.

-16 Lee HT, Kim M, Song JH, Chen SWC, Gubitosa G, Emala CW: Sevoflurane mediated TGF-betal signaling in renal proximal tubule cells. Am J Physiol Renal Physiol 2008; 294:F371-F378.

-17 Lee HT, Kim M, Jan M, Penn RB, Emala CW: Renal tubule necrosis and apoptosis modulation by A1 adenosine receptor expression. Kidney Int 2007;71:1249-1261.

18 Lee HT, Emala CW: Characterization of adenosine receptors in human kidney proximal tubule (HK-2) cells. Exp Nephrol 2002;10: 383-392.

>19 Min JK, Yoo HS, Lee EY, Lee WJ, Lee YM: Simultaneous quantitative analysis of sphingoid base 1-phosphates in biological samples by o-phthalaldehyde precolumn derivatization after dephosphorylation with alkaline phosphatase. Anal Biochem 2002;303:167175.

20 Vessey DA, Kelley M, Zhang J, Li L, Tao R, Karliner JS: Dimethylsphingosine and FTY720 inhibit the SK1 form but activate the SK2 form of sphingosine kinase from rat heart. J Biochem Mol Toxicol 2007;21:273279.

-21 Lee HT, Emala CW: Adenosine attenuates oxidant injury in human kidney proximal tubular cells via A1 and A2a adenosine receptor activation. Am J Physiol Renal Physiol 2002;282:F844-F852.
22 Lee HT, Kim M, Kim J, Kim N, Emala CW: TGF-beta1 release by volatile anesthetics mediates protection against renal proximal tubule cell necrosis. Am J Nephrol 2007;27: 416-424.

23 Kohama T, Olivera A, Edsall L, Nagiec MM, Dickson R, Spiegel S: Molecular cloning and functional characterization of murine sphingosine kinase. J Biol Chem 1998;273: 23722-23728.

24 Merrill AH Jr, Schmelz EM, Dillehay DL, Spiegel S, Shayman JA, Schroeder JJ, Riley RT, Voss KA, Wang E: Sphingolipids - the enigmatic lipid class: biochemistry, physiology, and pathophysiology. Toxicol Appl Pharmacol 1997;142:208-225.

25 Spiegel S: Sphingosine 1-phosphate: a ligand for the EDG-1 family of G-protein-coupled receptors. Ann NY Acad Sci 2000;905:54-60.

26 Zhang H, Desai NN, Olivera A, Seki T, Brooker G, Spiegel S: Sphingosine-1-phosphate, a novel lipid, involved in cellular pro liferation. J Cell Biol 1991;114:155-167.

27 Jo SK, Bajwa A, Awad AS, Lynch KR, Okusa MD: Sphingosine-1-phosphate receptors: biology and therapeutic potential in kidney disease. Kidney Int 2008;73:1220-1230.

28 McVerry BJ, Garcia JG: Endothelial cell barrier regulation by sphingosine 1-phosphate. J Cell Biochem 2004;92:1075-1085.

29 Peng X, Hassoun PM, Sammani S, McVerry BJ, Burne MJ, Rabb H, Pearse D, Tuder RM, Garcia JG: Protective effects of sphingosine 1-phosphate in murine endotoxin-induced inflammatory lung injury. Am J Respir Crit Care Med 2004;169:1245-1251.

30 Schaphorst KL, Chiang E, Jacobs KN, Zaiman A, Natarajan V, Wigley F, Garcia JG: Role of sphingosine-1 phosphate in the enhancement of endothelial barrier integrity by platelet-released products. Am J Physiol Lung Cell Mol Physiol 2003;285:L258-L267.

31 Sun X, Shikata Y, Wang L, Ohmori K, Watanabe N, Wada J, Shikata K, Birukov KG Makino H, Jacobson JR, Dudek SM, Garcia JG: Enhanced interaction between focal adhesion and adherens junction proteins: involvement in sphingosine 1-phosphateinduced endothelial barrier enhancement. Microvasc Res 2009;77:304-313.
32 Venkatachalam MA, Bernard DB, Donohoe JF, Levinsky NG: Ischemic damage and repair in the rat proximal tubule: differences among the S1, S2, and S3 segments. Kidney Int 1978; 14:31-49.

33 Dinour D, Agmon Y, Brezis M: Adenosine: an emerging role in the control of renal medullary oxygenation? Exp Nephrol 1993;1: $152-157$.

-34 Lee HT, Xu H, Ota-Setlik A, Emala CW: Oxidant preconditioning protects human proximal tubular cells against lethal oxidant injury via p38 MAPK and heme oxygenase-1. Am J Nephrol 2003;23:324-333.

35 Greene EL, Paller MS: Oxygen free radicals in acute renal failure. Miner Electrolyte Metab 1991;17:124-132.

>36 Paller MS, Neumann TV: Reactive oxygen species and rat renal epithelial cells during hypoxia and reoxygenation. Kidney Int 1991; 40:1041-1049.

37 Salahudeen AK: Role of lipid peroxidation in $\mathrm{H}_{2} \mathrm{O}_{2}$-induced renal epithelial (LLC-PK1) cell injury. Am J Physiol 1995;268:F30-F38.

38 Sheridan AM, Fitzpatrick S, Wang C, Wheeler DC, Lieberthal W: Lipid peroxidation contributes to hydrogen peroxide induced cytotoxicity in renal epithelial cells. Kidney Int 1996;49:88-93.

-39 Bektas M, Jolly PS, Muller C, Eberle J, Spiegel S, Geilen CC: Sphingosine kinase activity counteracts ceramide-mediated cell death in human melanoma cells: role of Bcl-2 expression. Oncogene 2005;24:178-187.

40 Edsall LC, Cuvillier O, Twitty S, Spiegel S, Milstien S: Sphingosine kinase expression regulates apoptosis and caspase activation in PC1 2 cells. J Neurochem 2001;76:1573-1584.

41 Davis MD, Clemens JJ, Macdonald TL, Lynch KR: Sphingosine 1-phosphate analogs as receptor antagonists. J Biol Chem 2005; 280:9833-9841. 